\title{
An Assessment of Structural Measures for Flood-prone Lowlands with High Population Density along the Keelung River in Taiwan
}

\author{
LUNG-SHENG HSIEH ${ }^{1, \star}$, MING-HSI HSU ${ }^{2}$ and MING-HSU LI $^{3}$ \\ ${ }^{1}$ National Science and Technology Center for Disaster Reduction, Taipei, Taiwan, ROC; \\ ${ }^{2}$ Department of Bioenvironmental Systems Engineering, National Taiwan University, Taipei, \\ Taiwan, ROC; ${ }^{3}$ Institute of Hydrological Sciences, National Central University, Taiwan, ROC
}

\begin{abstract}
Midstream of the Keelung River Basin in Northern Taiwan has become highly urbanized and densely populated area. Flood inundation along riversides frequently occurred during typhoons or rainstorms. Three protection measures, including constructions of highlevel protection levees, a diversion channel, and a detention reservoir, were proposed for flood mitigation. The main purpose of this study is to evaluate the flood mitigation performance of the three proposed structural measures by using combined hydrologic analyses and hydraulic routings. A semi-distributed parallel-type linear reservoirs rainfall-runoff model was used for estimating the surface runoff. Furthermore, a 1-D dynamic channel routing model was coupled with a two-dimensional inundation model to simulate the hydraulic characteristics of river flooding and overland flow. Simulation results of flood stages, runoff peak discharges, and inundation extent under design rainfall scenarios were chosen as the criteria for evaluation. The results showed a diversion channel is superior to the other two measures for flood mitigation of the study area. After the process of environmental impact assessment, a revised diversion channel approach has been approved for construction as the major structural measure.
\end{abstract}

Key words: flood-prone lowlands, flood inundation, flood mitigation, inundation model, structural measures.

\section{Introduction}

Taiwan is located at the intersection of the Euro-Asian continent and the Pacific Ocean, at the tracks of typhoons during summer and fall. The annual rainfall of the island is plentiful and may reach $2,500 \mathrm{~mm}$, in which almost $80 \%$ falls from May to October on account of Mei-yu fronts and typhoons. Rivers in Taiwan are short with steep slope and meandering that is favorable to the occurrence of midstream/downstream flooding when heavy rainstorms fall in the basin. In recent years, the rapid urbanization without sufficient floodplain management resulted in highly

^ Author for correspondence. E-mail: 1shsieh@ncdr.nat.gov.tw 
developed and densely populated zones over riversides. The existent hydraulic facilities were unable to provide enough flood protection. As a result, flooding is one of the worst natural hazards causing serious economic and social impacts in Taiwan.

Because of limited land resources and dense population in Taiwan, it is pressing to find available land for urban development. Without proper regulations for floodplain management, most river basins in Taiwan were overdeveloped with communities that are highly vulnerable to flooding disasters. Sijhih City located at the midstream of the Keelung River Basin (Figure 1) was seriously flooded four times during past decade by typhoons causing disastrous losses of lives and properties. Three long-term structural measures, including high protection levees with pumping stations, a diversion channel, and a detention reservoir, were proposed for resolving the flooding problem in Sijhih City. The levees are considered to be constructed along riversides to prevent river floods with pumping stations for draining inland water to the river. The locations of the diversion work and detention reservoir were selected based on field survey of watershed geology and past basin management planning.

The main purpose of this study is to evaluate the flood mitigation effects of three proposed structural measures by using both hydrologic analyses and hydraulic routings. Prior to performing hydraulic evaluations, hydrologic analyses were applied to simulate rainfall-runoff scenarios for design storms. Hydrologic analyzing processes include the Log-Pearson type III distribution (Phien and Jivajirajan, 1983) for estimating total

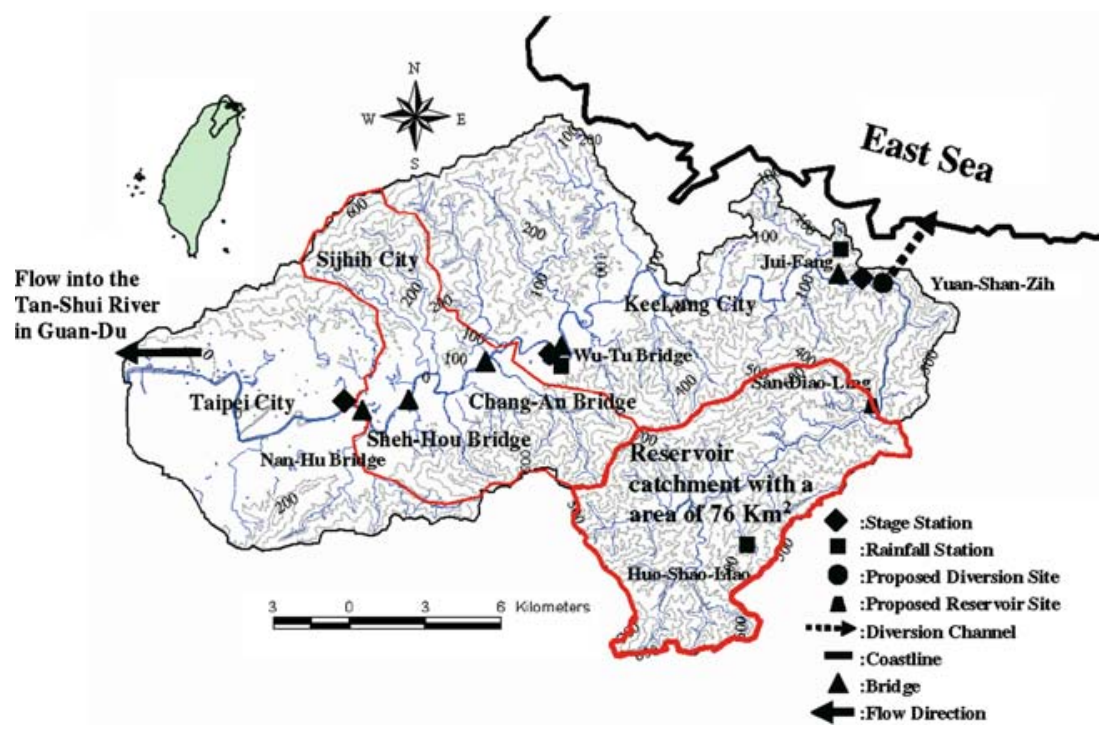

Figure 1. Topography of the Keelung River Basin in Northern Taiwan. 
rainfall depths at various return periods and durations, Horner's equation for describing rainfall intensity-duration-frequency relationship, the alternate block method (Chow et al., 1988) for distributing temporal rainfall pattern, and a semi-distributed parallel-type linear reservoir rainfall-runoff model (Hsieh and Wang, 1999) for estimating the induced surface runoff. In the phase of hydraulic analyses, 1-D dynamic channel routing model (Hsu et al., 2000a,b) and 2-D overland flow model (Hsu et al., 2002) were coupled to simulate the hydraulic characteristics of river and overland flooding, respectively. From model simulations of the design storms, the reductions of flood stages, inundation extent, and peak discharges were adopted as the criteria for evaluating flood mitigation performance for each proposed measure.

\section{Flooding Problems of the Study Area}

As shown in Figure 1, the study area, Sijhih City, is located in the midstream of the Keelung River Basin. The basin has a drainage area of $501 \mathrm{~km}^{2}$, a mainstream length of $86 \mathrm{~km}$, and an extremely high annual rainfall over 3,900 $\mathrm{mm}$. The topographic features of the middle reach have numerous tributaries almost orthogonal to the mainstream, which cause the difficulty in drainage during flood seasons.

Sijhih City is next to the Taipei metropolis. After the year 1961, the convenient traffic communication and regional economic growth brought the results of many newly built communities along valley hillsides of the Keelung River and mass population migrating to this area. Figure 2 shows the variations of land-use conditions, such as farmland, building-land, and road-land in Sijhih City. From this figure, it is noted that the building-land area in 1996 (563 ha) is 4.2 times than that in 1961 (134 ha), and the roadland area is 10 times larger. From 1961 to 1996, the building-land and road-land areas have increased 600 ha that is roughly equal to the decrease of the farmland area. As a result, impermeable area will increase and influence the regional hydrological balance, such as the increase of flood volume and peak discharge, and early arrival of peak discharge.

Figure 3 shows the population statistics every 5 years for Sijhih City from 1956 to 2001. An evidently quick growth was found from 1991 to 2001. According to the latest population census in 2003, the total population reaches 169,955 persons and the population density becomes 2,386 persons per square kilometer in Sijhih City. Since almost all housing environment and industry-commercial activities concentrate in the low-lying valley of the Keelung River, hence the real population density there should be higher than the averaged statistical value of Sijhih City. 


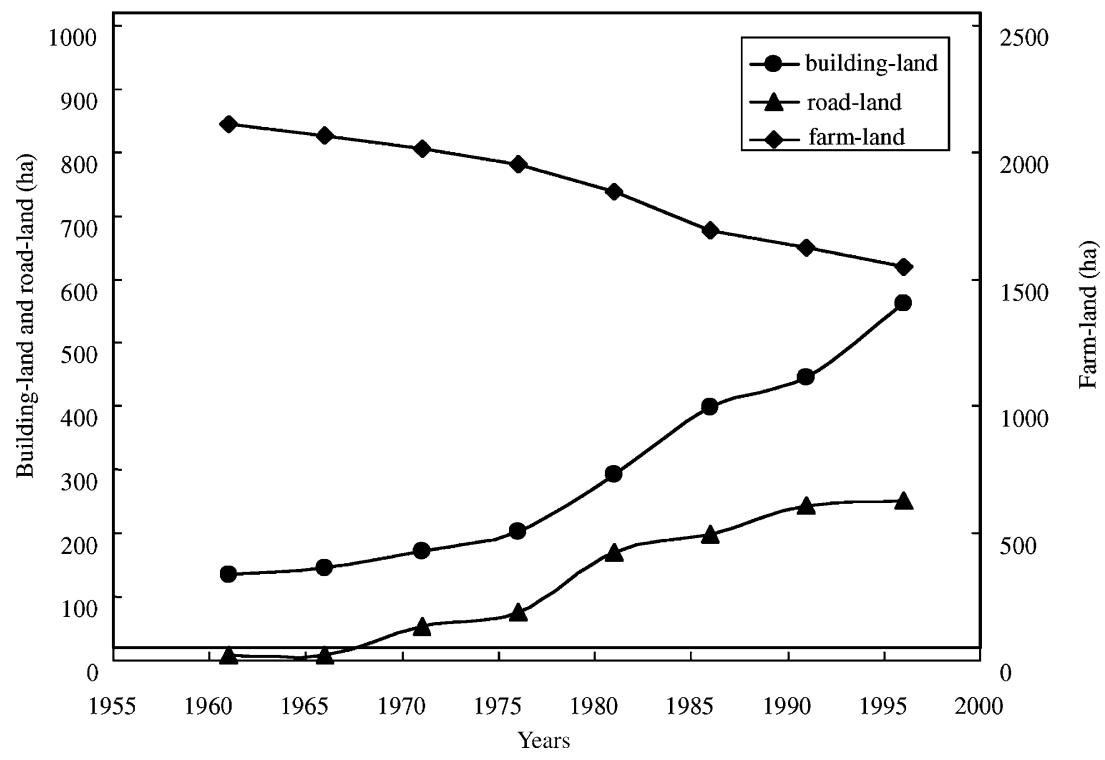

Figure 2. Variations of land-use conditions in Sijhih City.

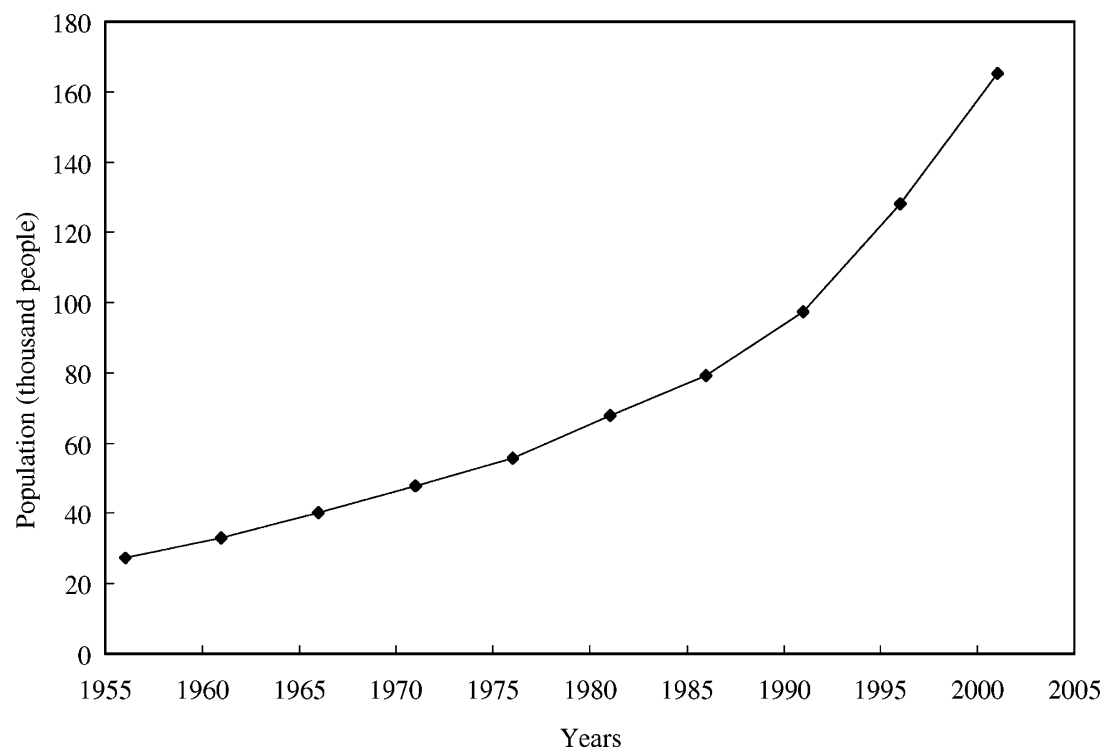

Figure 3. The growing population in Sijhih City.

From 1998 to 2001, a total of four disastrous typhoons, including Zeb (1998), Babs (1998), Xangsane (2000), and Nari (2001), resulted in serious over-bank flooding and inundation in Sijhih City. Table I lists the 
Table I. Observed rainfall intensities and surveyed inundation of typhoon events

\begin{tabular}{|c|c|c|c|c|c|c|c|}
\hline \multirow[t]{3}{*}{ Typhoon events } & \multirow{2}{*}{\multicolumn{4}{|c|}{$\begin{array}{l}\text { Observed rainfall } \\
\text { Maximum accumulated } \\
\text { rainfall }(\mathrm{mm})\end{array}$}} & \multicolumn{3}{|c|}{ Surveyed inundation } \\
\hline & & & & & \multirow[t]{2}{*}{$\begin{array}{l}\text { Area } \\
\text { (ha) }\end{array}$} & \multirow[t]{2}{*}{$\begin{array}{l}\text { Average } \\
\text { depth }(\mathrm{m})\end{array}$} & \multirow[t]{2}{*}{$\begin{array}{l}\text { Maximum } \\
\text { depth }(\mathrm{m})\end{array}$} \\
\hline & $1-\mathrm{h}$ & 6-h & $12-\mathrm{h}$ & 24-h & & & \\
\hline Nari (2001) & 120 & 303 & 466 & 759 & 617 & 3.5 & 8.5 \\
\hline Xangsane (2000) & 49 & 287 & 464 & 723 & 441 & 2.5 & 7.5 \\
\hline Zeb (1998) & 57 & 204 & 366 & 597 & 291 & 2.0 & 4.0 \\
\hline Babs (1998) & 37 & 200 & 356 & 469 & 275 & 1.8 & 3.8 \\
\hline Lynn (1987) & 79 & 318 & 490 & 784 & 610 & 3.0 & 7.5 \\
\hline
\end{tabular}

observed rainfall intensities and surveyed inundation of the study area in recent typhoon events. The accumulated rainfalls of various durations in these events were above the current capacity of regional drainage systems and flood control structures. It should be noted that although Typhoon Nari and Typhoon Lynn had similar amounts of the 24-h rainfall and intensities, but the induced inundation depth of Typhoon Nari were much higher than that of Typhoon Lynn due to rapid urbanization from 1987 to 2001. Urbanization often leads to the increase of impermeable areas and results in total runoff volume increase too. Figure 4 is the surveyed inundation extent of Typhoon Nari in the study area which showed almost all communities along the river were submerged by the floods. Based on above descriptions, it can be seen that Sijhih City is a flood-prone lowland with high population density.

\section{Proposed Flood Mitigation Measures}

Owing to the urgent requirement on resolving the flooding problems of the study area, the structural measures were determined as the main strategy and the non-structural measures, such as flooding warning system, retarding basin delimited, and disaster insurance etc., should be adopted as supplements to strengthen flood sustainability. For the structural measures phase, the authorities proposed three approaches of long-term flood mitigation measures as below:

\subsection{HIGH-LEVEL PROTECTION LEVEES AND PUMPING STATIONS}

In Taiwan, high-level protection levees with pumping stations were widely used to protect urban areas against river flooding. The construction of 


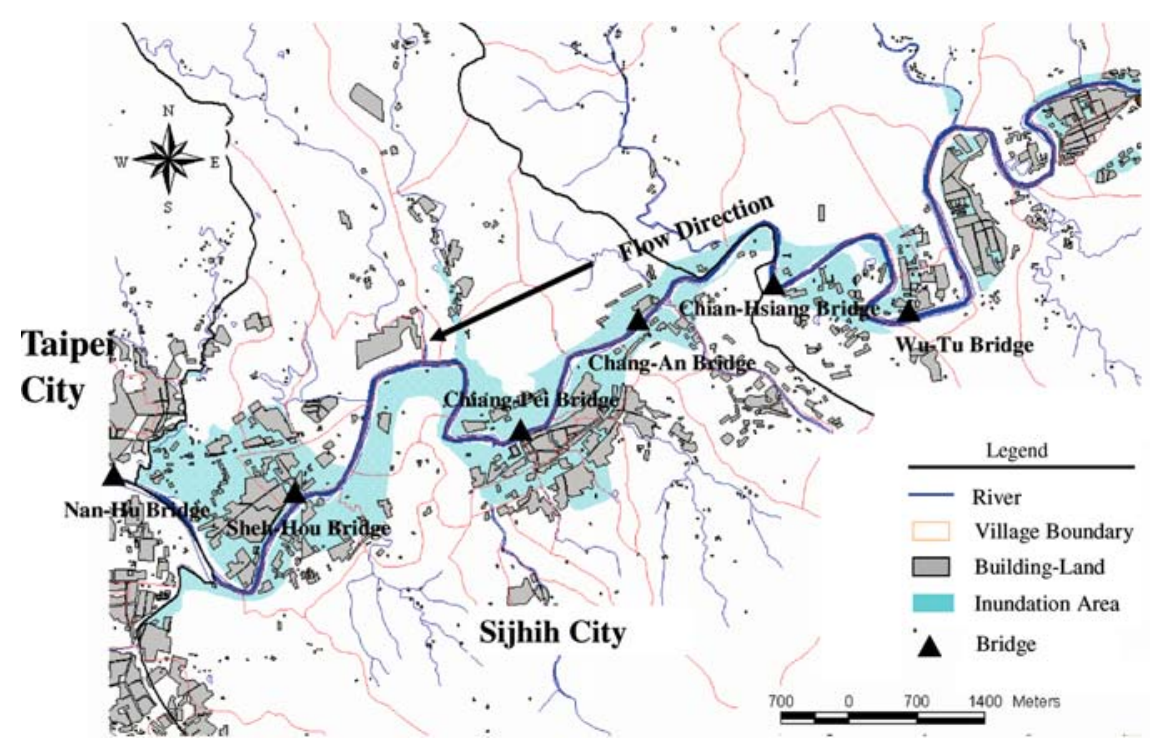

Figure 4. The surveyed inundation extent along the Keelung River (shown in shaded area) caused by Typhoon Nari.

levees along the Keelung River with the capability of defeating 200-year rainfall, as those used for the downstream reaches, was proposed for evaluation, while the water of lowlands and tributaries is controlled through the operation of pumping stations. The capacities of pumping stations are designed to account for $70 \%$ of peak discharges from tributary basins under 5-year rainfalls. Because the Keelung River near Sijhih City is a contracted reach with $100 \mathrm{~m}$ in width due to the high development in floodplain, the height of high-level protection levees may have $5 \mathrm{~m}$ above the current banks along the river in order to sustain the flood discharge of the 200-year storm.

\subsection{DIVERSION CHANNEL}

The second approach is to reduce the flood discharge of the main stream through a diversion channel. Yuan-Shan-Zih next to Jui-Fang town as shown in Figure 1 was selected to be the starting point of the diversion channel because it has the shortest distance to the East Sea than anywhere else. The diversion channel will include inlet-outlet structures, a main tunnel with a diameter of $10 \mathrm{~m}$, and an inlet weir etc. The inlet weir was designed to divert the flood water into the diversion channel when the mainstream discharge exceeds $90 \mathrm{~m}^{3} / \mathrm{s}$. The maximum discharge capacity for the diversion channel was $1000 \mathrm{~m}^{3} / \mathrm{s}$. 


\subsection{DETENTION RESERVOIR}

Construction of a detention reservoir at a suitable upstream location provides another feasible strategy for flood mitigation with the advantage of water resources management through reservoir operations. This approach seems to resolve flooding and water resources problems simultaneously. Based on the preliminary study, San-Diao-Ling as shown in Figure 1 was chosen to be the most suitable reservoir site with a catchment area of $76.0 \mathrm{~km}^{2}$, an effective storage capacity of 19.05 million $\mathrm{m}^{3}$ with a dam height of $55 \mathrm{~m}$. The maximum outflow discharge of $100 \mathrm{~m}^{3} / \mathrm{s}$ was designed to regulate the river discharges for flood mitigation during a flood period except for the emergency release.

\section{Evaluation Tools}

A series of systematic approaches, including rainfall frequency analysis, runoff analysis, and hydraulic analysis, was applied to assess the mitigation effects of the three aforementioned structural measures.

\subsection{DESIGN STORM}

The design rainfall were generated by frequency analysis with past rainfall data. First, the Log-Pearson type III distribution (Phien and Jivajirajan, 1983) was used to estimate the total rainfall depths at each rainfall station for various return periods and durations. Second, Horner's equation was applied to setup the correlation of rainfall intensity, duration, and frequency. While the design rainfall was assumed to be uniform in space, the alternate block method (Chow et al., 1988) was then employed to estimate the temporal distribution. The design hyetograph generated by this method specifies the precipitation depth occurring in $n$ successive time intervals of equal duration $\delta t$ over a total duration $T_{d}=n \delta t$. After selecting the design return period, the intensity is found from the intensity-duration-frequency curve for each of the durations $\delta t, 2 \delta t, 3 \delta, \ldots$, and the corresponding precipitation depth is given by the product of intensity and duration. By taking differences between successive precipitation depth values, the amount of precipitation can be added for each additional unit of time $\delta t$. These increments, or blocks, are reordered into a time sequence with the maximum intensity occurring at the center of the required duration $T_{d}$ and the remaining blocks arranged in descending order alternately to the right and left of the central block to form the design hyetograph. Figure 5 shows the 200-year rainfall hyetograph which has a total rainfall depth of $772 \mathrm{~mm}$ in $24 \mathrm{~h}$ with a peak rainfall intensity of $95.3 \mathrm{~mm} / \mathrm{h}$ applied for driving runoff and hydraulic routings. 


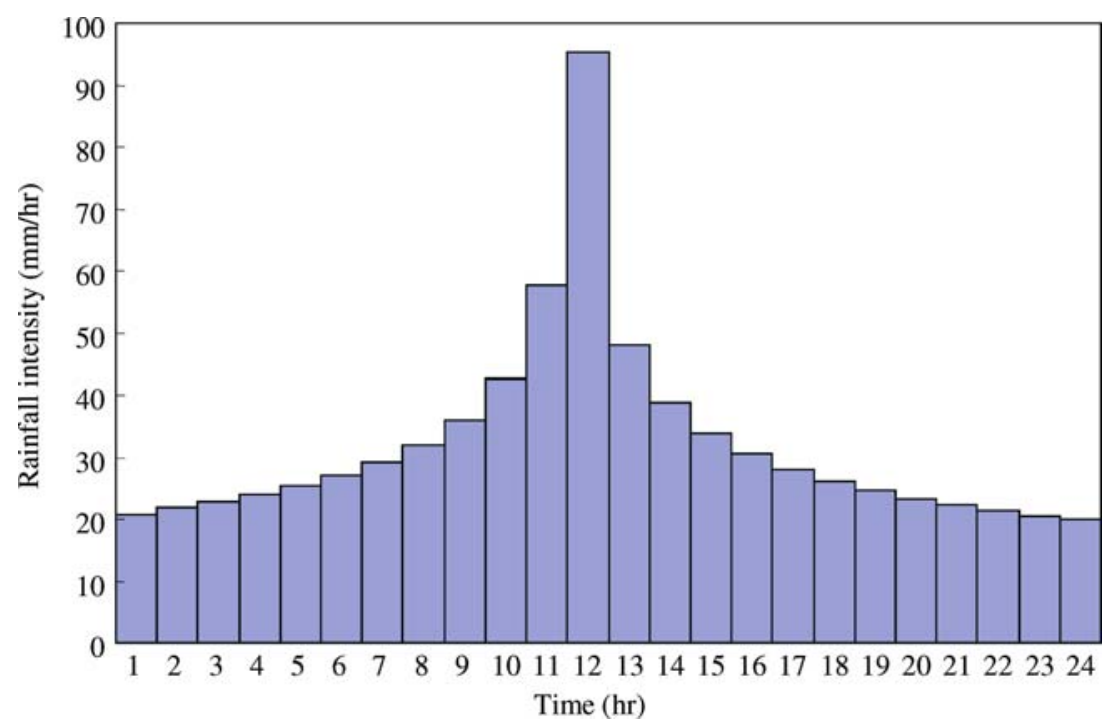

Figure 5. The design storm hyetograph of 200-year return period.

\subsection{RAINFALL-RUNOFF ANALYSIS}

For the simulations of the surface runoffs on upstream basins which provide the boundary conditions in hydraulic routings, a semi-distributed parallel-type linear reservoir rainfall-runoff model (Hsieh and Wang, 1999) was applied to describe the relationship between the rainfall and runoff. A watershed in the model was conceptually represented by a series of $n$ linear reservoirs, each having a different storage constant $K$. If a unit-volume inflow flows through the $n$ linear reservoirs, the outflow $q_{n}$ from the $n$-th reservoir, i.e. the instantaneous unit hydrograph, can be expressed as follows (Hsieh and Wang, 1999):

$$
\begin{aligned}
U_{n}(t)= & q_{n}(t)=\int_{0}^{t} U_{n-1}(\tau) \frac{1}{K_{n}} e^{\frac{-(t-\tau)}{K_{n}} \mathrm{~d} \tau} \\
& =\left\{\begin{array}{l}
\frac{1}{K_{1}} e^{-\frac{t}{K_{1}}}, \quad N=1 \\
\sum_{i=1}^{N} \frac{K_{i}^{N-2}}{\prod_{j=1, j \neq i}^{N}\left(K_{i}-K_{j}\right)} e^{-\frac{t}{K_{1}}}, \quad N \geq 2
\end{array}\right.
\end{aligned}
$$

where $K_{n}$ is the storage constant of the $n$-th linear reservoir; $N$ is the total number of cells in the watershed.

To simplify the model derivation, a watershed as shown in Figure 6 can be treated as a number of sub-watersheds, called cell units, based on the 


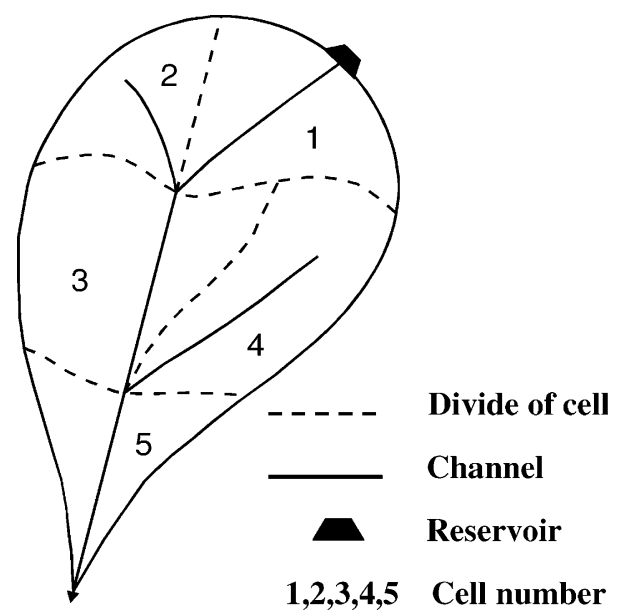

Figure 6. Illustration of rainfall-runoff model cells in a watershed.

stream network and the land-use data, each having a cell number from upstream to downstream. Suppose that a unit-volume excess rainfall is uniformly and instantaneously distributed throughout the whole drainage area, all possible paths of flow (Rodriguez-Iturbe et al., 1979) that the rainfall takes to arrive at the outlet of the watershed can be classified as shown in Figure 7.

The $n$-th path of flow consists of the overland flow of $n$-th sub-watershed and a number of stream reaches in series. The runoff of each sub-watershed can be described by the concept model of the linear reservoir. The instantaneous unit hydrograph of each path at the outlet of the watershed can be derived by a series of linear reservoirs and their flow paths. Finally, the total direct runoff at the outlet of the watershed can be found by the instantaneous unit hydrograph convoluting with the effective rainfall.

\subsection{HYDRAULIC ROUTING}

Hydraulic routing is used to simulate the flood flows in the channel and ground surface. The flood flow in a channel can be described by the 1-D gradually varied flow equation (Cunge et al., 1980; Lai et al., 1986; Chaudhry, 1993; Hsu et al., 2003), i.e. the St. Venant equation

$$
\begin{aligned}
& \frac{\partial A}{\partial t}+\frac{\partial Q}{\partial x}-q_{l}=0 \\
& \frac{\partial Q}{\partial t}+\frac{\partial}{\partial x}\left(\frac{Q^{2}}{A}\right)-g A\left(S_{0}-\frac{\partial d}{\partial x}-S_{\mathrm{f}}\right)-V q_{l}=0
\end{aligned}
$$




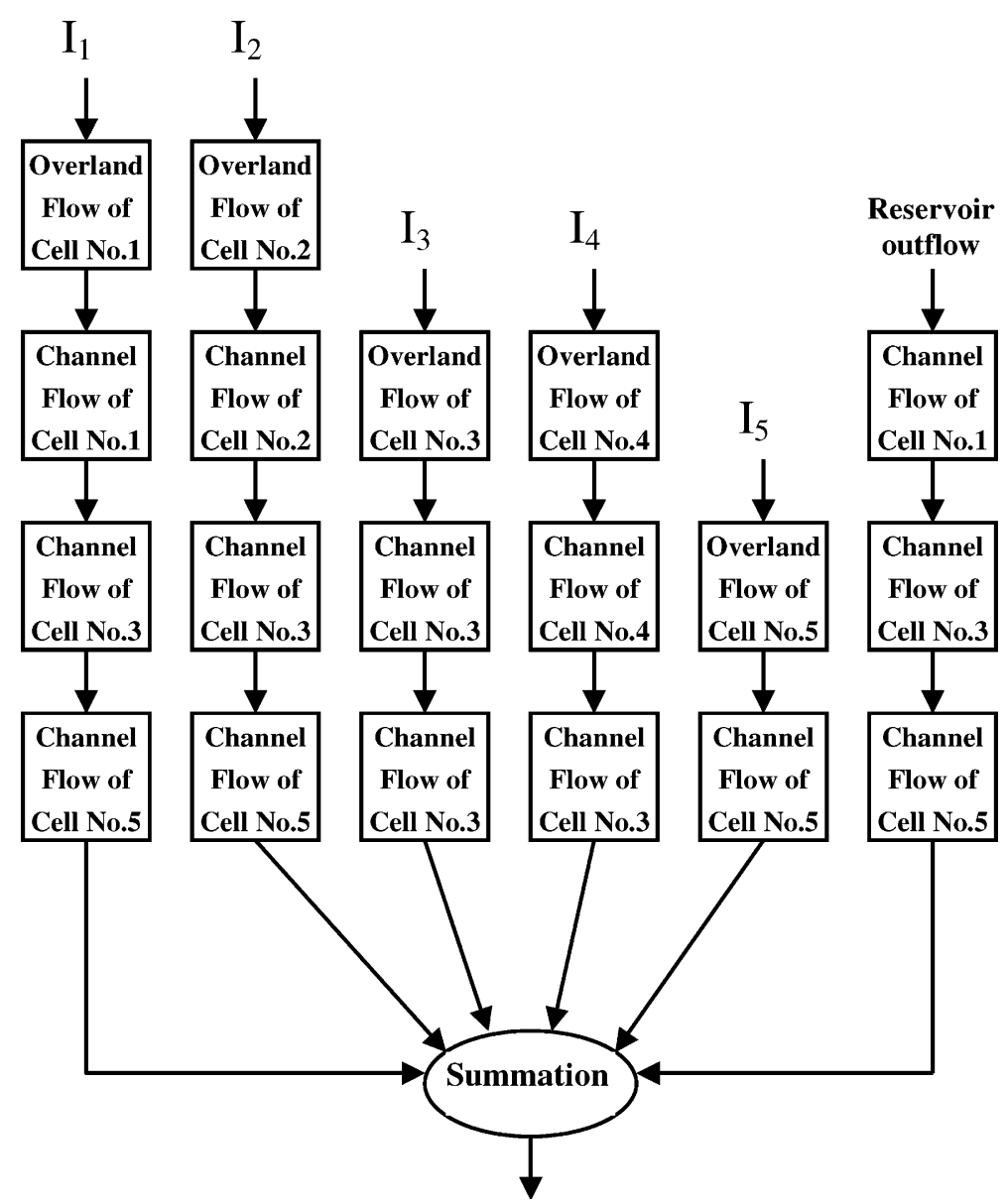

Figure 7. Structure of the rainfall-runoff model.

in which $A$ and $Q$ are the cross-sectional area and discharge of channel; $q_{l}$ is the lateral flow per unit length flowing from outlet of ground surface to channel; $x$ is the coordinate in longitudinal direction; $g$ is the gravitational acceleration; $S_{0}$ is the bed slope; $d$ is the flow depth; $S_{\mathrm{f}}$ is the friction slope and equal to $n_{\mathrm{c}}^{2} Q|Q| / A^{2} R^{4 / 3}$; where $R$ is the hydraulic radius and $n_{\mathrm{c}}$ is the Manning's roughness of channel; $V$ is the longitudinal component of the mean lateral inflow velocity. The four-point Preissmann scheme (Cunge et al., 1980), which has been extensively used to solve the St. Venant equation, is herein applied.

The flood flow in ground surface can be governed by the simplified 2-D zero-inertial wave model including the 2-D continuity and depth-averaged 
momentum equations (Hromadka et al., 1989; Tayfur, et al., 1993; Wasantha Lal, 1998; Hsu et al., 2002) shown as below:

$$
\begin{aligned}
& \frac{\partial d}{\partial t}+\frac{\partial(u d)}{\partial x}+\frac{\partial(v d)}{\partial y}=q \\
& -\frac{\partial h}{\partial x}=u\left[\frac{n^{2}|u|}{d^{4 / 3}}+\frac{q}{d g}\right] \\
& -\frac{\partial h}{\partial y}=v\left[\frac{n^{2}|v|}{d^{4 / 3}}+\frac{q}{d g}\right]
\end{aligned}
$$

where $d$ is water depth; $u, v$ is velocity component in $x$ - and $y$-direction, respectively; $h$ is water stage; $q$ is excess rainfall intensity; $n$ is the Manning's roughness of ground surface. In the above equations, $d, u$, and $v$ are the dependent variables to be solved. It should be noted that the Manning's roughness of ground surface is the only parameter to be verified. Equations (4)-(6) can be solved by various numerical schemes such as Alternating Direction Explicit (ADE) and Alternating Direction Implicit (ADI) schemes (Wasantha Lal, 1998). For the present study, a two-step ADE was employed since ADE allows an initial condition with zero water depth and velocity. The finite difference method was applied to discretize Equations (4)-(6) which can be found elsewhere (Chang et al., 2000; Hsu et al., 2000a,b).

Based on natural watershed divides, the study area was divided into two regions, one for runoff simulations and another for inundation simulations. Upstream mountainous runoffs computed from rainfall-runoff analyses were applied as the upstream boundary inflows and lateral tributary inflows for both 1-D and 2-D hydraulic routings, which provided a linkage between hydrologic analyses and hydraulic routings.

To demonstrate the suitability of hydraulic models herein employed, the water-level profile and inundation depth-range data from Typhoon Babs (1998) were selected to calibrate Manning's roughness coefficients for both 1-D dynamic channel and 2-D overland flow routings. The calibration results of the 1-D dynamic channel routing model on flood stage profiles were illustrated in Figure 8, which showed acceptable agreement between the observed data and simulated stages. Manning's coefficients of the channel were found in a range between 0.03 and 0.06 . Figure 9 shown the comparison of inundated areas between the flood records and results of the 2-D diffusive overland-flow routing model for Typhoon Babs, which showed acceptable agreement between computed and observed inundation areas. 


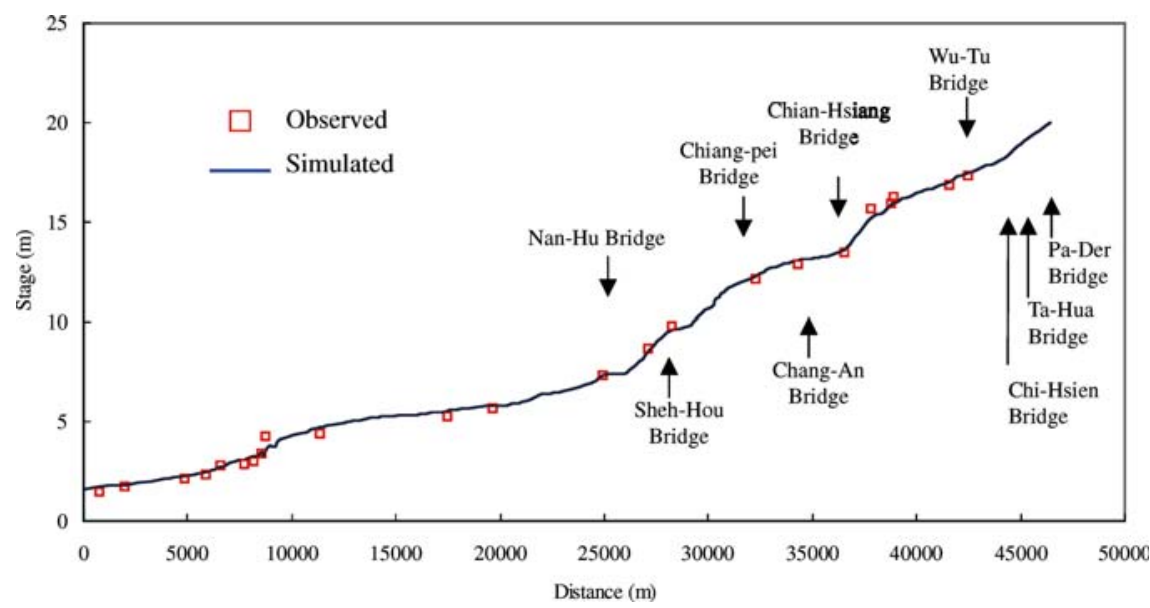

Figure 8. Observed and simulated peak stage on some control sections for 1-D unsteady flow model calibration.

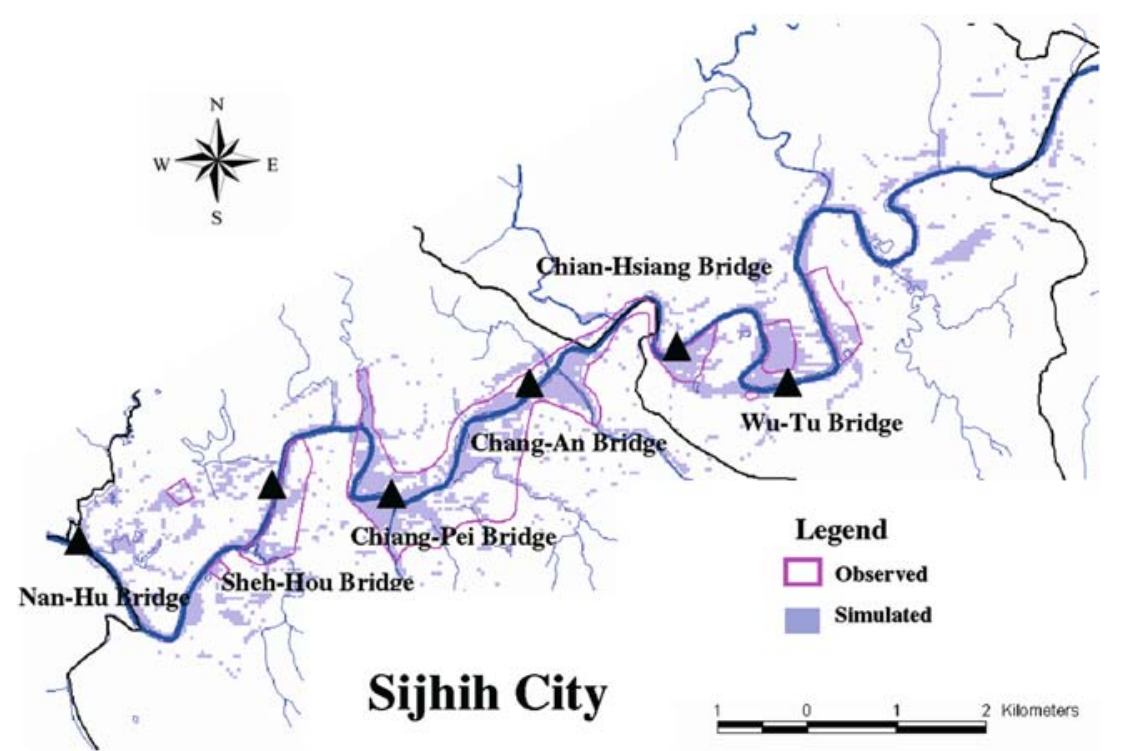

Figure 9. Observed and simulated inundation areas for Typhoon Babs in 1998.

\section{Results and Discussions}

It should be noted that the evaluation of flood mitigation effects of structural measures performed in this study only relies on hydrological and hydraulic practices, rather than other factors, such as cost-effective analysis, environmental impact assessment, and socio-economic impact 
assessment, which were not included in the present study. The evaluated results for all measures were summarized as follows.

\subsection{FLOOD STAGES}

Figure 10 shows the flood stage profiles for all structural measures under the 200-year rainfall. The figure reveals that the 200-year flood stages under the present flood-protection measures (without further structural measure) are higher than the current bank elevations, therefore, over-bank flooding shall occur. For both diversion and detention measures, the computed flood stages are lower than the bank elevation. For the high-protection levees with pumping stations, the flood stages are higher than those without further structural measure because the flood was confined inside the main channel. The effects on the flood stage reduction by the diversion work and detention reservoir have the similar performance and are better than that by the high-protection levees. Table II lists the stages for various measures and the bottom plate elevations of important traffic road bridges in Sijhih City. From the table, one can see that the flood stage exceeds the bottom plate elevations at some bridges and results in flooding. In the table, the stage reductions were defined as the differences of the average flood stage with structural measure and that without structural measure. On an average, the high-protection levees, diversion channel, and detention reservoir will contribute the stage reductions on flood mitigations in an

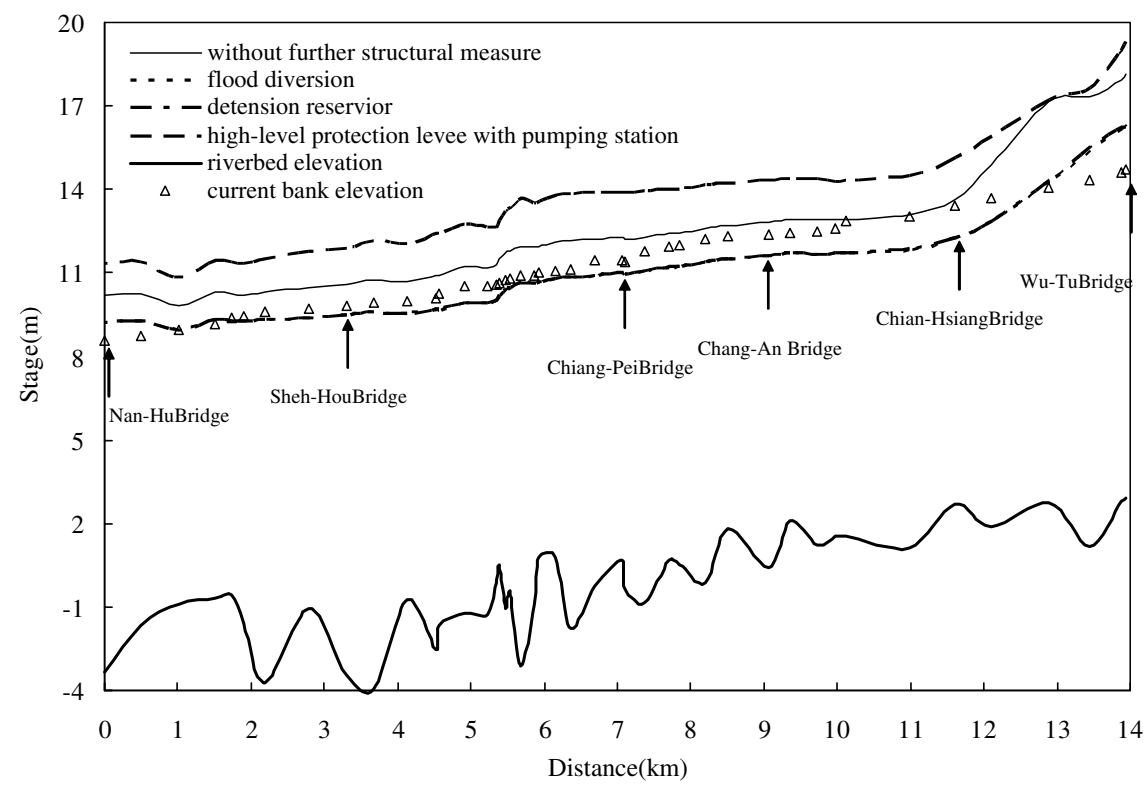

Figure 10. The simulated flood peak stage profiles for proposed structural measures. 
Table II. Stage comparisons of various structural measures for 200-yr storm

\begin{tabular}{llllll}
\hline Control sections & $\begin{array}{l}\text { Bottom } \\
\text { elevations of } \\
\text { bridge-plate }(1)\end{array}$ & $\begin{array}{l}\text { No } \\
\text { measure } \\
(2)\end{array}$ & $\begin{array}{l}\text { Levees } \\
(3)\end{array}$ & $\begin{array}{l}\text { Diversion } \\
\text { channel } \\
(4)\end{array}$ & $\begin{array}{l}\text { Detention } \\
\text { reservoir } \\
(5)\end{array}$ \\
\hline Wu-Tu Bridge & 15.00 & 18.13 & 19.32 & 16.33 & 16.27 \\
Chian-Hsiang Bridge & 15.00 & 13.65 & 15.15 & 12.28 & 12.29 \\
Chang-An Bridge & 11.30 & 12.84 & 14.33 & 11.60 & 11.63 \\
Chiang-Pei Bridge & 11.60 & 12.26 & 13.93 & 11.02 & 11.03 \\
Sheh-Hou Bridge & 11.01 & 10.59 & 11.91 & 9.49 & 9.50 \\
$\begin{array}{l}\text { Nan-Hu Bridge } \\
\text { Average stage }\end{array}$ & 12.19 & 10.21 & 11.37 & 9.24 & 9.23 \\
reduction & & & -1.39 & 1.29 & 1.29 \\
\hline
\end{tabular}

Unit: meter.

amount of $-1.39,1.29$ and $1.29 \mathrm{~m}$, respectively. Therefore, the high-protection levees may increase river flood stages and enhance the risk of overbank flooding disaster.

\subsection{PEAK DISCHARGE}

Table III shows the comparison of peak discharge at several important control sections along the main channel for the diversion work and detention reservoir measures. From the table, it is shown that the peak discharges are gradually increasing from upstream toward downstream for diversion measure and detention reservoir, but do not have such tendency for no measure. The main reason is that the flood discharge of the case without protective measure have exceeded the conveyance capacity of the

Table III. Mitigation effects of diversion and detention reservoir measures on peak discharge dissipation at control sections

\begin{tabular}{|c|c|c|c|c|c|}
\hline \multirow[t]{2}{*}{ Sections } & \multirow{2}{*}{$\begin{array}{l}\text { No } \\
\text { measure } \\
\left(\mathrm{m}^{3} / \mathrm{s}\right)(1)\end{array}$} & \multicolumn{2}{|c|}{ Diversion measure } & \multicolumn{2}{|c|}{ Detention reservoir } \\
\hline & & $\begin{array}{l}\text { Peak } \\
\text { discharge } \\
\left(\mathrm{m}^{3} / \mathrm{s}\right)(2)\end{array}$ & $\begin{array}{l}\text { Discharge } \\
\text { dissipation } \\
(\%)(3)^{\mathrm{a}}\end{array}$ & $\begin{array}{l}\text { Peak } \\
\text { discharge } \\
\left(\mathrm{m}^{3} / \mathrm{s}\right)(4)\end{array}$ & $\begin{array}{l}\text { Discharge } \\
\text { dissipation } \\
(\%)(5)\end{array}$ \\
\hline Wu-Tu Bridge & 1836.40 & 1274.80 & 30.58 & 1222.00 & 33.46 \\
\hline Chang-An Bridge & 1738.85 & 1426.68 & 17.95 & 1338.40 & 23.03 \\
\hline Sheh-Hou Bridge & 1771.40 & 1463.30 & 17.39 & 1451.13 & 18.08 \\
\hline Nan-Hu Bridge & 2039.29 & 1570.40 & 22.99 & 1554.89 & 23.75 \\
\hline
\end{tabular}

a $(3)=((1)-(2)) /(1)$. 
main channel for study area, and resulted in over-bank flows which reduced the discharge in main channel before reaching downstream bridges. The overflow flood may again discharge into the main channel of downstream finally. On the contrary, the discharges of the flood under the diversion work or a detention reservoir measure were restricted in the main channel, and gradually increased due to the inflows from confluent tributaries.

Besides, it is noted that the dissipation rate of peak discharge was gradually decreasing from upstream toward downstream. The dissipation rate is defined by dividing the peak-discharges difference between with and without measures by the no-measure discharge. For example, the dissipation rate of peak discharge was $30.58 \%$ at $\mathrm{Wu}-\mathrm{Tu}$ Bridge (upstream) and $22.99 \%$ at Nan-Hu Bridge (downstream) for the diversion channel, 33.46\% at $\mathrm{Wu}-\mathrm{Tu}$ Bridge (upstream) and $23.75 \%$ at Nan-Hu Bridge (downstream) for the detention reservoir. The reason for having limited mitigation effect downstream is the contribution of flood water by numerous tributaries flowing into the main channel, which may increase the difficulty on conveying floods toward downstream. In general, the diversion and detention reservoir measures can provide a similar effect on peak discharge mitigation. For high-protection levee measures, no significant peak discharge reduction was found.

\subsection{INUNDATION DEPTH/RANGE}

Table IV lists a simple statistical analysis of the inundation range/depth for each measure. Without any protection measure, the total inundation areas are 642 ha, including 247 ha with an inundation depth over $3 \mathrm{~m}$. For the measures of high-protection levees, diversion, and detention reservoir, the total inundation areas are 469, 535, and 546 ha, respectively, which are 173, 107, and 96 ha less than that without any protection plan. It should be noted that the inundated areas with a depth under $3 \mathrm{~m}$ have no significant difference between all three measures and the case without any

Table IV. Comparisons of inundation depths/areas for proposed structural measures

\begin{tabular}{lllll}
\hline \multirow{2}{*}{ Depth $(\mathrm{m})$} & \multicolumn{3}{l}{ Inundation areas (ha) } \\
\cline { 2 - 5 } & No measure & Levees & Diversion & Detention reservoir \\
\hline $0.50<\mathrm{d}<1.00$ & 118 & 127 & 122 & 118 \\
$1.00<\mathrm{d}<2.00$ & 148 & 152 & 163 & 166 \\
$2.00<\mathrm{d}<3.00$ & 129 & 100 & 115 & 110 \\
$3.00<\mathrm{d}$ & 247 & 90 & 135 & 152 \\
Total & 642 & 469 & 535 & 546 \\
\hline
\end{tabular}


measure. Significant diminutions for areas with an inundation depth over $3 \mathrm{~m}$ were observed for all three proposed measures. The levee measure has the least inundation areas, showing significant diminution areas on depth over $3 \mathrm{~m}$. The diversion measure has smaller inundation areas than the detention reservoir. The reason is many low-laying regions along riversides will be included into the main channel when the high-protection levees were constructed. Although, inundation area is the smallest for the case of high-protection levees, once levees are broken due to overtopping the catastrophic flood disaster may occur. This means the high-levee measure has a high potential of flood disasters. Figure 11 shows the simulated results of inundation range/depth for the case of the diversion plans.

Table $\mathrm{V}$ shows the priority rank of three proposed measures based on the above discussions. From this synthetic assessment table, we can find that the diversion plan is superior to the other two measures. However, current assessment results presented in this study were only from the viewpoints of hydrologic and hydraulic practices. The final decision should be made with the considerations of other evaluation criteria, such as costeffective analysis and environmental impact assessment. If the diversion work was chosen as a long-term mitigation plan, biological and environmental impacts on the outlet harbor and the geological feasibility should be evaluated and carefully concerned. The forthcoming land levy along riversides, locations of pumping station, and local drainage planning are the future important issues if the levee measure was selected. The land levy of

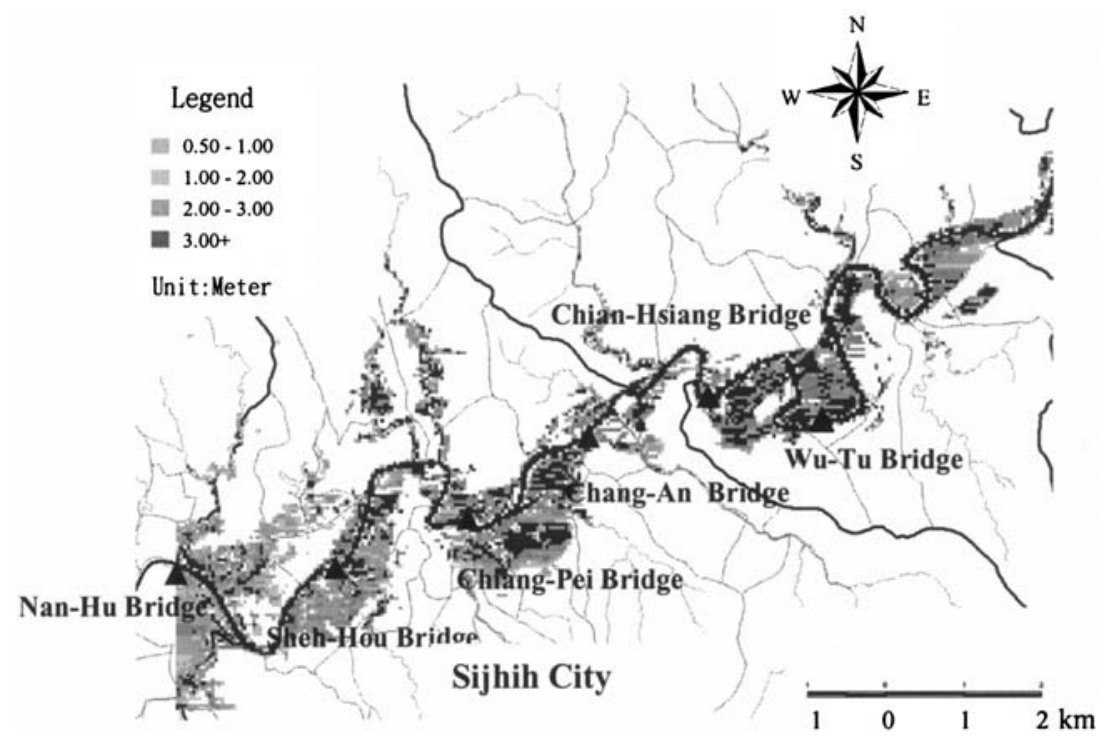

Figure 11. Inundation depth/range for the flood diversion structure measures. (maximum diversion capacity of $1,000 \mathrm{~m}^{3} / \mathrm{s}$ ). 
Table $V$. The priority rank evaluated for proposed structural measures

\begin{tabular}{llll}
\hline Criteria & \multicolumn{2}{l}{ Structural measures } \\
\cline { 2 - 4 } & Levees & Diversion & Detention reservoir \\
\hline Flood stage & Secondary & Best & Best \\
Peak dissipation & Worst & Best & Best \\
Inundation depth/range & Best & Secondary & Worst \\
\hline
\end{tabular}

submerged areas, environmental and social impacts, the operational longevity, and the geological feasibility are the other important issues to be concerned when the detention reservoir will be chosen as the long-term flood mitigation measure.

\section{Selection of Protection}

The diversion work was decided as the final decision-making measures by the authorities in Taiwan based on studies presented herein, as well as other factors (not included in this study), such as land levy difficulties, environmental and biological impacts, traffic influence, finance plan, and construction time, etc. To strengthen the flood mitigation effects of the diversion plans for Sijhih City, the maximum diversion capacity was modified from 1,000 to $1,310 \mathrm{~m}^{3} / \mathrm{s}$. The simulated results of inundation depth/ range for the revised diversion plans are shown in Table VI and Figure 12. The average peak discharge dissipation is now about $29.24 \%$ and the average flood stage reduction is $1.59 \mathrm{~m}$ which is better than the original diversion plan. Now, the construction of diversion work has been started since June 5, 2002 and it is expected to be completed on November 4, 2004 (website: http://keelung.wra.gov.tw). The layout of the diversion channel is shown in Figure 13 which includes inlet-outlet structures, excavation of a

Table VI. Mitigation effect of a revised diversion measure with a capacity of $1,310 \mathrm{~m}^{3} / \mathrm{s}$

\begin{tabular}{|c|c|c|c|c|c|c|}
\hline \multirow[t]{2}{*}{ Sections } & \multicolumn{3}{|c|}{ Peak discharge } & \multicolumn{3}{|l|}{ Stage } \\
\hline & $\begin{array}{l}\text { No } \\
\text { measure } \\
\left(\mathrm{m}^{3} / \mathrm{s}\right)(1)\end{array}$ & $\begin{array}{l}\text { Revised } \\
\text { measure } \\
\left(\mathrm{m}^{3} / \mathrm{s}\right)(2)\end{array}$ & $\begin{array}{l}\text { Discharge } \\
\text { dissipation } \\
(\%)(3)\end{array}$ & $\begin{array}{l}\text { No } \\
\text { measure } \\
(\mathrm{m})(4)\end{array}$ & $\begin{array}{l}\text { Revised } \\
\text { measure } \\
(\mathrm{m})(5)\end{array}$ & $\begin{array}{l}\text { Stage } \\
\text { reduction } \\
(\mathrm{m})(6)\end{array}$ \\
\hline Wu-Tu Bridge & 1836.40 & 1251.10 & 31.87 & 18.13 & 15.85 & 2.27 \\
\hline Chang-An Bridge & 1738.85 & 1169.20 & 32.76 & 12.84 & 11.22 & 1.62 \\
\hline Sheh-Hou Bridge & 1771.40 & 1312.50 & 25.91 & 10.59 & 9.29 & 1.30 \\
\hline Nan-Hu Bridge & 2039.29 & 1500.20 & 26.43 & 10.21 & 9.04 & 1.17 \\
\hline Average & & & 29.24 & & & 1.59 \\
\hline
\end{tabular}




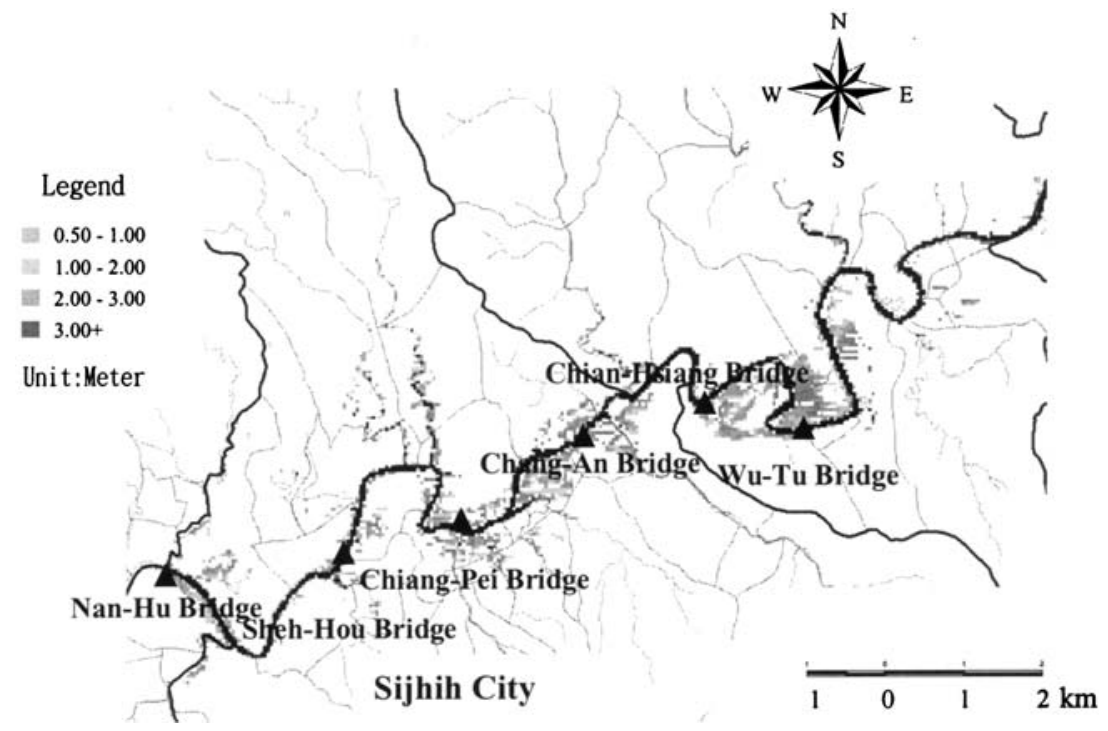

Figure 12. Inundation depth/range for the revised flood diversion structure measures. (maximum diversion capacity of $1310 \mathrm{~m}^{3} / \mathrm{s}$ ).

tunnel with a diameter of $12 \mathrm{~m}$ and a length of $2.45 \mathrm{~km}$, a length of $199 \mathrm{~m}$ closed conduit. The diversion function will be operated when the river flood stage exceeds $63 \mathrm{~m}$ that corresponds with a discharge of $110 \mathrm{~m}^{3} / \mathrm{s}$ in the main channel. The maximum diversion capacity is $1,310 \mathrm{~m}^{3} / \mathrm{s}$ diverted from the main channel flow of $1,620 \mathrm{~m}^{3} / \mathrm{s}$ at 200 -year return period flood. The remnants $310 \mathrm{~m}^{3} / \mathrm{s}$ is discharged to the Keelung River downstream. Besides the construction of diversion measure, several supplementary measures, such as improved region drainage system, implementation of hillside protection work, enhancement of basin runoff retardation, establishment of flood forecasting and inundation warning system, management of flood plain control, and promotion of flood insurance, have been adopted to enhance the flood mitigation of diversion measure. The damage losses by future typhoons or rainstorms are expected to be diminished.

\section{Conclusions}

Sijhih City, located at the midstream of the Keelung River Basin, is a flood-prone lowland with high population density. This work presented three proposed long-term structural measures, including high-protection levees with pumping stations, a diversion channel, and a detention reservoir to resolve the flood problem of the study area. From both hydrological and hydraulic considerations, we can find that the diversion plan is superior to the other two measures for solving the regional flood problems. 


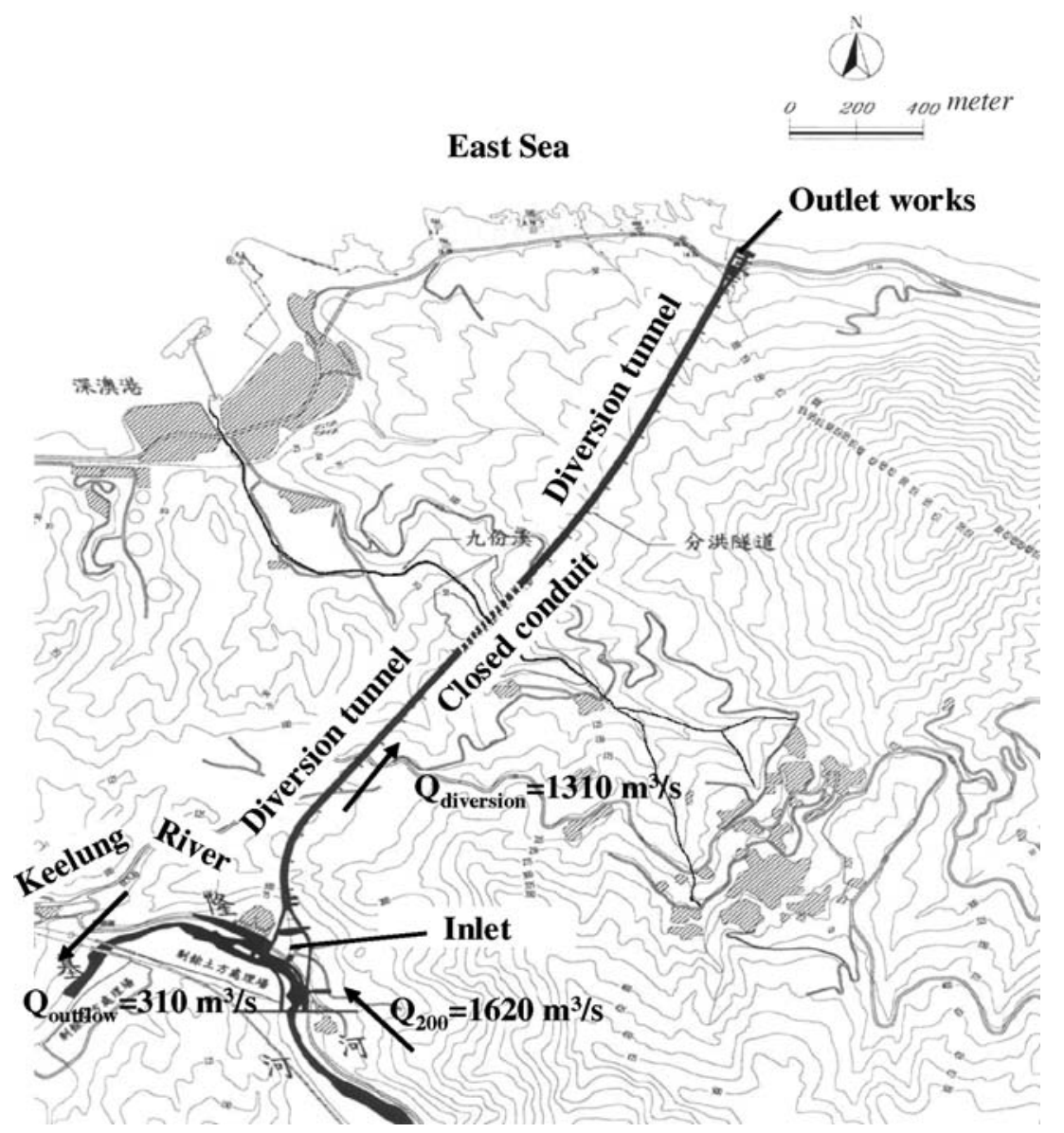

Figure 13. The layout of the Yuan-Shan-Zih diversion.

But the structural mitigation approach can only provide a limited degree of protection. The important point is disasters cannot be resolved thoroughly, while property damage and human loss should be reduced as minimum as possible. Therefore, non-structural measures, such as developing real-time flood forecasting and warning system, establishing hazards mitigation organization, practicing emergency response actions, and promoting the idea of flood insurance, may supplement the shortcoming of structural measures and reduce the impact by typhoon floods.

\section{Acknowledgments}

This study was supported by National Science Council, ROC through the office of National Science and Technology Program for Hazards Mitigation. Valuable hydrologic and topographic data of the Keelung 
River was provided by Water Conservancy Agency. During the reviewing process, the reviews provided valuable comments on improving the quality of this manuscript. The authors are grateful for their considerable assistance.

\section{References}

Chang, T. J., Hsu, M. H., Teng, W. H., and Huang, C. J.: 2000, AA GIS-assisted distributed watershed model for simulating flooding and inundation, J. Am.Water Resour. Assoc. 36(5), 975-988.

Chaudhry, M. H.: 1993, Open-channel Flow, Prentice-Hall Inc, New Jersey.

Chow, V. T., Maidment, D., and Mays, L. W.: 1988, Applied Hydrology, McGraw-Hill Book Company, New York.

Cunge, J. A., Holly, F. M., and Verwey, A.: 1980, Practical Aspects of Computational River Hydraulics, Pitman Publishing Ltd, London.

Hromadka, T. V. II, Walker, T. R., Yen, C. C., and DeVries, J. J.: 1989, Application of the U.S.G.S. diffusion hydrodynamic model for urban floodplain analysis, Water Resour. Bull. 25(5), 100-110.

Hsieh, L. S. and Wang, R. Y.: 1999, A semi-distributed parallel-type linear reservoir rainfallrunoff model and its application in Taiwan, J. Hydrol. Process. 13(8), 1247-1268.

Hsu, M. H., Lin, S. H., and Fu, J. C.: 2000a, Flood forecast system for Tanshui River Basin (IV) flood forecasting model, Proc. Hydroinformatic 2000, Iowa City, IA, USA.

Hsu, M. H., Chen, S. H., and Chang, T. J.: 2000b, Inundation simulation for urban drainage basin with storm sewer system, J. Hydrol. 234(1-2), 171-177.

Hsu, M. H., Chen, S. H., and Chang, T. J.: 2002, Dynamic inundation simulation of storm water interaction between sewer system and overland flows, J. Chin. Inst. Eng. 25(2), 171177.

Hsu, M. H., Fu, J. C., and Liu, W. C.: 2003, Flood routing with real-time stage correction method for flash flood forecasting in the Tanshui River, Taiwan, J. Hydrol. 283, 267-280.

Lai, C. T., Chow, V. T., and Yen, B. C.: 1986, Numerical modeling of unsteady open-channel flow, In: Advances in Hydroscience, Vol. 14, Academic Press, Orlando, FL, pp. 133-161.

Phien, H. N. and Jivajirajan, T.: 1983, Applications of the Log Pearson type-3 distribution in hydrology, J. Hydrol. 73, 359-372.

Rodriguez-Iturbe, I., Devoto, G., and Valdes, J. B.: 1979, Discharge response analysis and hydrologic similarity :the interrelation between the geomorphologic IUH and the storm characteristics, Water Resour. Res. 15(6), 1435-1444.

Tayfur, G., Kavvas, M. L., Govindaraju, R. S., and Storm, D. E.: 1993, Applicability of St. Venant equations for two-dimensional overland flows over rough infiltration surfaces, $J$. Hydraulic Eng. ASCE 119(1), 51-63.

Wasantha Lal, A. M.: 1998, Performance comparison of overland flow algorithms, $J$. Hydraulic Eng. ASCE 124(4), 342-349. 